\title{
A shallow water ecosystem: rice-fields. The relevance of cyanobacteria in the ecosystem.
}

\author{
Eduardo Fernández-Valiente* and Antonio Quesada \\ Departamento de Biología. Universidad Autónoma de Madrid, E-28049 Madrid, Spain \\ * Corresponding author, tel: 34-914978186, fax: 34-914978344, email: eduardo.fernandez@uam.es
}

\begin{abstract}
In this paper we review the knowledge of the ecology of the largest freshwater ecosystem on Earth: the rice-fields, and in particular the rice-fields from Valencia (Spain) making a special consideration to the cyanobacteria present in this ecosystem. Rice-fields are artificial shallow aquatic ecosystems in which the land management and the agricultural practices together with the rice plant growth govern the major environmental variables affecting the aquatic biota and its relationships. Primary producers are dominated typically by macrophytic algae as Chara and cyanobacteria, both planktonic and benthic (beside the rice plants). Most rice-fields can be considered nutrient replete, since the fertilization inputs and the low ratio volume/surface make that main nutrients are typically available. Under these circumstances other environmental variables as photosynthetically active radiation availability or filtration rates and predation may explain the growth limitation of primary producers. Irradiance availability identify two periods within the cultivation cycle: when plants are short, irradiance is not limiting and some water chemistry variables (as $\mathrm{pH}$, oxygen and dissolved inorganic $\mathrm{C}$ concentrations) change drastically as a function of the primary production; when plants are large and the canopy is intense, then irradiance is limiting and the water chemistry changes only slightly along the day. $\mathrm{N}_{2}$-fixation is a main activity in the $\mathrm{N}$ cycle in rice-fields, since $\mathrm{N}_{2}$-fixing cyanobacteria represent an important fraction of the aquatic biota of this ecosystem. We will discuss in detail the relevance of this process from the ecological point of view.
\end{abstract}

Keywords: cyanobacteria, $\mathrm{N}_{2}$-fixation, photosynthesis, primary production, rice-fields, shallow water ecosystems, wetlands

\section{RESUMEN}

En este artículo revisamos el conocimiento sobre la ecología del mayor ecosistema de agua dulce de la Tierra: los arrozales, y en particular de los arrozales de Valencia (España), haciendo especial hincapié en las cianobacterias presentes en este ecosistema. Los arrozales son ecosistemas acuáticos someros artificiales en los que su gestión y prácticas agrícolas, junto con el desarrollo de la planta de arroz gobiernan las variables ambientales más relacionadas con la biota acuática incluyendo sus interrelaciones. Los productores primarios están típicamente dominados por macrófitos algales tales como Chara y por cianobacterias tanto bénticas como planctónicas, además de por las plantas de arroz. La mayoría de los arrozales se pueden considerar con exceso de nutrientes, ya que la entrada de nutrientes de origen agrícola así como la baja relación volumen/superficie hace que los principales nutrientes inorgánicos se encuentren presentes en altas concentraciones. Bajo estas circunstancias otras variables ambientales como la radiación fotosintéticamente activa o las tasas de filtración y la predación pueden explicar la limitación de crecimiento de los productores primarios. La disponibilidad de radiación permite distinguir dos periodos durante el ciclo de cultivo: cuando las plantas son bajas, la radiación no es limitante y algunas variables químicas del agua (tales como $\mathrm{pH}$ o las concentraciones de oxígeno disuelto o de C inorgánico disuelto) cambian drásticamente en función de la producción primaria; y cuando las plantas son altas y la sombra que producen éstas es elevada, entonces la radiación puede ser limitante y las características químicas sólo cambian ligeramente a lo largo del día. La fijación de $\mathrm{N}_{2}$ es una actividad fundamental en el ciclo del $\mathrm{N}$ en los arrozales, ya que las cianobacterias fijadoras de $\mathrm{N}_{2}$ representan una importante fracción de la biota acuática de este ecosistema. Discutiremos en detalle la influencia de este proceso desde un punto de vista ecológico.

Palabras Clave: cianobacterias, fijación de $N_{2}$, fotosíntesis, producción primaria, arrozales, ecosistemas acuáticos someros, humedales 


\section{RICE-FIELDS: AN AQUATIC ECOSYSTEM}

Rice-fields is the most extensive freshwater aquatic ecosystem on Earth with more than 1.5 million $\mathrm{km}^{2}$. In Spain rice-fields cover about 80000 ha and in the area of interest for this review (Valencia) about 13000 ha. Whitton et al. (1988a; 1988b; $1988 \mathrm{c}$ ) described in a series of 5 papers the ecology of deep water rice-fields from Bangladesh. More recently Roger (1996) published a comprehensive monograph about the rice-fields, from an agronomical point of view, but considering as well the ecology of this ecosystem. European ricefields have not been investigated so extensively, although some papers describe from the ecological point of view the rice-fields from France and Spain (e.g. Minzoni et al, 1988; Forés \& Comín, 1992; Quesada et al., 1997)

Rice-fields typically require flooding during a variable period of time. The duration and depth of flooding depends upon the water availability, but in Spain the irrigation keeps a constant water level, (typically between 5 and $20 \mathrm{~cm}$ ), which is the most appropriate for rice cultivation, during about 4 months of each year. These characteristics depict the rice-fields as a peculiar aquatic ecosystem in which the water layer is very shallow, but relatively constant during a fraction of the year, because of that, the interaction sediment-water is very important and likely plays a major role on the biological activities. Moreover, the rice plant growth triggers severe shifts, making rice-fields a highly dynamic ecosystem because of the changes in the physical and chemical characteristics of water and sediments that take place during the cultivation cycle. Land management and agricultural practices also have an important influence over the ecological characteristics of the rice-fields, because of the physical disruption of sediments, as well as the input of nutrients or pesticides which impair the natural community structure and stability, favouring the dominance of rice. Finally, the harvest of rice represents an important export of biomass from the ecosystem of more than 10 tons of organic matter per hectare and year.

\section{RICE CROPPING SYSTEM}

In Valencian rice-fields, as in other European rice-fields, the crop begins in mid-April with the deep placement of fertilizers under dry conditions. The usual fertilization rates are around 100-150 kg N ha-1 year ${ }^{-1}$ and 20-75 kg P ha-1 year ${ }^{-1}$. Flooding starts the first week of May and then the seeds are sown. At the end of June there is a short period of dry land, lasting ten days, when pesticides and sometimes more fertilizers are applied. During July and August the fields remain flooded, and at the beginning of September flooding stops and fields are allowed to dry. The harvest is undertaken at the end of September. In some areas, fields are flooded again during December and January for duck hunting (Quesada et al., 1995).

\section{MAJOR ENVIRONMENTS AND ACTIVITIES}

Flooding and the presence of rice plants lead to the differentiation of microenvironments in the rice-field ecosystem: floodwater, surface-oxidized soil, reduced soil, rice plants (submerged plants and rizosphere), plow layer and subsoil. These environments differ in their physical, chemical and trophic characteristics. (Roger et al., 1993). The most pertinent microenvironments for this paper are the floodwater, the oxidized soil and the rice plants. The floodwater is a photic, aerobic environment where aquatic communities of primary producers and consumers recycle nutrients and provide organic matter to the soil. Major activities in the floodwater includes photosynthesis and respiration, and photodependent biological $\mathrm{N}_{2}$ fixation by free-living and symbiotic cyanobacteria. The floodwater is subjected to large variations in irradiance, temperature, $\mathrm{pH}, \mathrm{O}_{2}$ concentration and nutrient status (Whitton et al., 1988c; Quesada et al., 1995). The lightscreening effect of the rice canopy induces a rapid decrease of light reaching the floodwater. Light penetration is also decreased by floating 
macrophytes, plankton and the turbidity resulting from agronomical practices and the activity of benthic invertebrates. Light reaching the floodwater have a major influence on other variables such as temperature, $\mathrm{O}_{2}$ concentration, DIC concentration and $\mathrm{pH}$.

The oxidized soil layer is a photic aerobic environment, a few millimetres thick, with a positive redox potential. A continuous exchange takes place between floodwater and the oxidized soil. Major activities include: aerobic decomposition of organic matter by aerobic bacteria, photosynthesis by cyanobacteria and algae, photodependent $\mathrm{N}_{2}$ fixation by free-living cyanobacteria and photosynthetic bacteria; nitrification by ammonium and nitrite oxidizers and methane oxidation. The depth of the oxidized layer, which is usually between 2 and $20 \mathrm{~mm}$, depends on the concentration of $\mathrm{O}_{2}$ dissolved in the floodwater, the reducing capacity of soil, the water percolation and the activity of soil fauna (Neue, 1988). After land preparation, algae develop at the soil surface and support grazing populations. Later in the crop cycle, organic matter accumulates at the soil surface and supports populations of invertebrates that recycle the nutrients (Roger, 1996).

As stated above, the rice plant affects the floodwater and surface soil environments by its shading effect. The submerged parts of rice plant provide a photic and aerobic environment that can be colonized by epiphytic bacteria and algae, and where populations of pulmonate molluses can also find mechanical support (Roger, 1996).

\section{PHOTOSYNTHETIC AQUATIC BIOMASS}

In spite of the wide dominance of rice plants, a conspicuous photosynthetic aquatic biomass composed by cyanobacteria, planktonic, filamentous and macrophytic algae and vascular macrophytes develop during the different phases of rice growth. Benthic, planktonic and epiphytic cyanobacteria are widespread in rice-fields, and typically about $50 \%$ of the cyanobacterial genera are heterocystous
(Whitton, 2000). Cyanobacterial flora includes unicellular (Microcystis, Chroococcus), filamentous (Oscillatoria, Lyngbya, Phormidium) and filamentous with heterocysts (Anabaena, Nostoc, Gloeotrichia) species. Eukaryotic algal flora includes unicellular phytoplanktonic (Chlorella; Cosmarium; Navicula); filamentous (Cladophora, Spirogyra, Oedogonium) and macrophytic (Chara; Nitella) species. Aquatic macrophytes includes submerged (Hydrilla, Najas), floating (Azolla, Lemna) and marginal land (Typha, Eichornia) species (Whitton et al., 1988b; Forés \& Comín, 1992; Roger, 1996).

Studies on cyanobacterial and algal successions have been performed in different ricefields all over the world (Gupta, 1966; Roger \& Reynaud, 1976; Grant et al., 1986). In spite of the differences found among rice-fields, a general trend can be proposed from these studies. Phytoplankton (mainly chlorophyceans and diatoms) develops early in the cultivation cycle until the tillering phase. From tillering to the initiation of panicle the photosynthetic aquatic biomass reaches its highest values. During this period filamentous green algae and non- $\mathrm{N}_{2}$-fixing cyanobacteria are dominant, although in some places also $\mathrm{N}_{2}$-fixing cyanobacteria become abundant. Also during this period submerged macrophytes develop dense populations. From panicle initiation to harvest, the total biomass decreases and $\mathrm{N}_{2}$-fixing cyanobacteria become dominant.

\section{Standing crop and productivity}

As in most of aquatic ecosystems the development of photosynthetic biomass depends on the availability of nutrients and light as well as on the grazing pressure. In fertilized and planted fields, the density and diversity of species depends on tiller density, in such a way that dense biomass can be found when the rice canopy is not too intense. Primary production of the aquatic communities in rice-fields is similar to that in eutrophic lakes, its daily production ranges between 0.2 and $2 \mathrm{~g} \mathrm{C} / \mathrm{m}^{2}$, which corre- 
sponds to $10-15 \%$ of rice primary production (Roger, 1996). Quantitative estimations of photosynthetic aquatic biomass per unit area deals mostly with cyanobacteria and macrophytes. The biomass of cyanobacterial blooms recorded in Valencian rice-fields range from 21 to $683 \mathrm{~kg}$ dry wt/ha, with a mean value of $135 \mathrm{~kg}$ dry $\mathrm{wt} / \mathrm{ha}$ and a median value of $72 \mathrm{~kg}$ dry wt/ha (unpublished results). These values are slightly lower than those reported for rice-fields from Philippines (range 8- $986 \mathrm{~kg}$ dry wt/ha; mean $204 \mathrm{~kg}$ dry wt/ha; median $177 \mathrm{~kg}$ dry wt/ha) (Roger, 1996). The biomass of aquatic macrophytes is usually higher than that of planktonic cyanobacteria. The biomass of submerged weeds (mainly Chara and Nitella) in rice-fields of Philippines averaged $1000 \mathrm{~kg}$ fresh wt/ha at tillering and $3000 \mathrm{~kg}$ fresh wt/ha at maturity, and the biomass of floating and marginal weeds averaged $1700 \mathrm{~kg}$ fresh wt/ha (Kulasooriya et al., 1981). In Valencian rice-fields Chara is the main macrophyte, its biomass range from 1400 to $13400 \mathrm{~kg}$ fresh wt/ha with a mean value of 6200 $\mathrm{kg}$ fresh wt/ha and a median value of $5500 \mathrm{~kg}$ fresh wt/ha (Ariosa, 2002). Similar values were recorded in the rice-fields of France (Vaquer, 1984) and southeast Asia (Misra et al., 1976).

\section{$\mathrm{N}_{2}$-fixing cyanobacteria}

Among photosynthetic aquatic organisms in rice-fields, cyanobacteria have received much attention due to their $\mathrm{N}_{2}$-fixing capacity. In a survey of 102 rice soils from Philippines, India, Malaysia and Portugal, Roger et al., (1987) found that heterocystous cyanobacteria were present in all samples. Their density ranged from $1.0 \cdot 10^{2}$ to $8.0 \cdot 10^{6}$ colony forming units $(\mathrm{CFU}) / \mathrm{cm}^{2}$, with a mean value of $2.5 \cdot 10^{5} \mathrm{CFU} / \mathrm{cm}^{2}$. Their abundance was positively correlated with the $\mathrm{pH}$ and the available $\mathrm{P}$ content of the soil.

In the rice-fields of Valencia (Spain), $\mathrm{N}_{2}$ - fixing cyanobacteria were also present in all the samples analysed, in amounts ranging from 1 to $3.5 \cdot 10^{3} \mathrm{CFU} / \mathrm{ml}$ in water samples and from $4 \cdot 10^{3}$ to $8.5 \cdot 10^{5} \mathrm{CFU} / \mathrm{cm}^{2}$ in sediment samples
(Quesada \& Fernández-Valiente, 1996). The number of cyanobacteria in soil decreased significantly from panicle initiation to harvest, namely during the period of development of surface blooms. Cyanobacterial blooms started to develop about fifty days after sowing, following a clear succession of strains. Blooms of Gloeotrichia and eventually of Cylindrospermum are first developed, followed subsequently by the appearance of blooms of several strains, principally from the genera Scytonema, Microchaete, Nostoc and Anabaena. At the end of the crop cycle blooms of Nostoc containing phycoerythrin usually develop, which can be favoured for the spectral quality of light reaching the water surface with predominance of green wavelengths (Quesada et al., 1998). The percentage of field area covered by cyanobacterial blooms increases with time, from $17 \%$ at the 75 day after sowing to $45 \%$ at the day 120 (Fernández-Valiente et al., 1996). Correlation analysis shows that cyanobacterial abundance in water and sediment is more influenced by water than by soil properties. Salinity, hardness, $\mathrm{Ca}$, and soluble reactive phosphate (SRP) correlated positively with $\mathrm{N}_{2}$-fixing cyanobacterial abundance. On the other hand, dissolved inorganic nitrogen (DIN) and the ratio DIN:SRP correlated negatively with cyanobacterial presence. However, DIN:SRP ratio better described the cyanobacterial distribution, with a threshold effect: below the Redfield ratio value (7.2 in mass units) cyanobacterial abundance was clearly higher (Quesada \& Fernández-Valiente, 1996).

The presence of epiphytic cyanobacteria on rice and other macrophytes have received little attention. Most data come from the deepwater rice-fields of Thailand and Bangladesh (Whitton \& Catling, 1986; Whitton et al., 1988b; Aziz \& Ahmed, 1991, 1992), where colonies of $\mathrm{N}_{2}$-fixing cyanobacteria (mainly Gloeotrichia) appear associated to deepwater rice tillers. In the ricefields of Valencia we have found that epiphytic cyanobacteria are more profusely associated to the macrophytic algae Chara than to rice plant. In fact, most of the $\mathrm{N}_{2}$-fixation in the ecosystem is associated to the epiphytic cyanobacteria growing on Chara (Ariosa, 2002). 


\section{RICE-FIELDS: A LUXURIANT ECOSYSTEM}

Rice-fields are aquatic ecosystems in which some of the typical limiting factors for the aquatic life are in excess. Typically inorganic nutrients (N, P and sometimes $\mathrm{C}$ ) are found at high concentration, because of the anthropogenic influence (e.g. fertilization, wastewater, agricultural procedures). For instance, in the Valencian rice-fields the dissolved nutrient content is on average (mean calculated from 2 to 6 sampling points in 1992, at three different moments of the flooding, June, July, September) $0.12{\mathrm{mg} \mathrm{N}-\mathrm{NO}_{3}}^{-} / 1,0.25 \mathrm{mg} \mathrm{N}-\mathrm{NH}_{4}^{+} / 1$ and 0.15 $\mathrm{mg} \mathrm{P}-\mathrm{PO}_{4}{ }^{3-} / 1$. Nevertheless, the nutrient concentration changes along the crop cycle, very much related with the agricultural techniques used in the rice-fields as well as with the sediment status. The absolute concentration values of each nutrient change drastically along the cycle (Fig. 1), as the DIN/SRP ratio does. In the represented year (1992), N/P changed from 6.8 (in mass units) in July to 1.04 in September, although nutrient concentration was consistently high (Martín-Trillo, 1995). Our observational data indicate that massive floating scums of $\mathrm{N}_{2}$ fixing cyanobacteria are related with low N:P ratios. At that moment the rice-fields can be considered as a chemostat in which fresh 'culture medium' is flowing around the floating photosynthetic biomass. Thus, the nutrient concentration at any certain moment should not be critical if it is in excess. Under those conditions other environmental or ecological variables, and not nutrients or DIN/SRP ratio, are presumably limiting the scum development. The rice-fields in Valencia can be considered a luxuriant aquatic ecosystem in which the nutrients are abundant and in many cases in excess. The nutrient excess is evidenced when comparing the nutrient concentrations of the water entering in a particular rice field (typically 1 ha in surface) and the water exiting the same field. These comparisons show that in more than $50 \%$ of the analysed moments, the fields did not take up nutrients at all, or even increased the nutrient

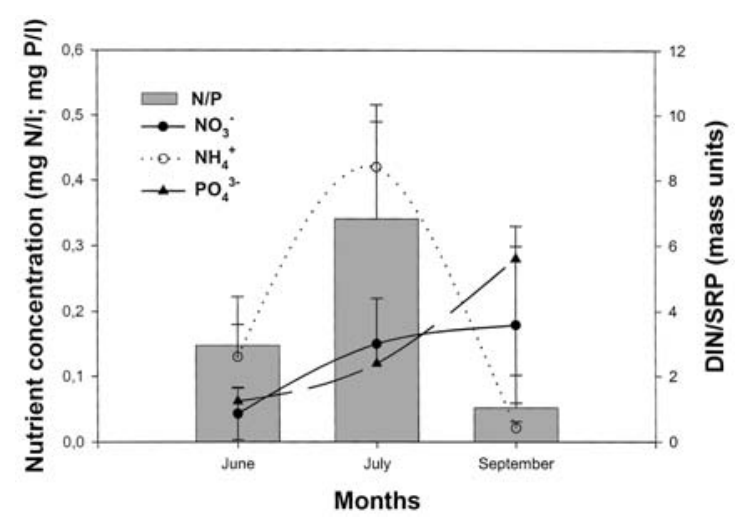

Figure 1. Nitrogen and phosphorus inorganic dissolved compounds in Valencian rice-fields. Data are an example of the typical water chemistry evolution found in Valencian ricefields. Data represent the seasonal variation (June, July and September) observed in 1992 in 2 to 6 sampling points. The error bars represent $1 / 2$ of the standard deviation of the mean. Nitrógeno y fósforo inorgánicos disueltos en los arrozales valencianos. Los datos se muestran como ejemplo de la variación habitual de la química del agua en los arrozales valencianos. Los datos representan la variación estacional (junio, julio y septiembre) observada en 1992 en de 2 a 6 puntos de muestreo del arrozal. Las barras de error representan la mitad de la desviación estándar de la media.

concentration in the exiting water. From those fields in which there was a negative nutrient balance (higher concentration at the entrance than at the exit), on average the fields took up about $58.5 \%$ of the entering nutrients, still leaving a considerable concentration of nutrients in the exiting water.

In this luxuriant ecosystem the DIN/SRP ratio is typically below the Redfield threshold, due mainly to the very high values of $P$ of agricultural origin. Thus, cyanobacteria are expected to dominate the ecosystem. But, can the Redfield threshold concept be used in a system in which nutrients are not limiting? Probably not, when the nutrients are not limiting, the ratio among them cannot govern the abundance or the activity of the organisms. Nevertheless, in another context, Quesada \& Fernández-Valiente (1996), showed that in an extensive area of the rice-fields, the DIN/SRP ratio and the abundance of $\mathrm{N}_{2}$-fixing cyanobacteria in water and in the sediment surface were directly correlated following a typical threshold distribution. 
FACTORS AFFECTING THE

\section{CYANOBACTERIAL BIOMASS}

\section{Light availability}

Light availability in wetland rice-fields is changing with the moment of the crop. When the rice plant is small enough not to shade the water layer underneath, light is not limiting for the photosynthetic organisms in all the watercolumn $(10 \mathrm{~cm}$ deep $)$. The primary producers found at this moment in the rice-fields should be high-light adapted organisms. As the growth season for rice continues, the plant increases in size and shades significantly the water layer, in that way an ecological succession is established from high light adapted to low light adapted organisms. Photosynthesis versus irradiance

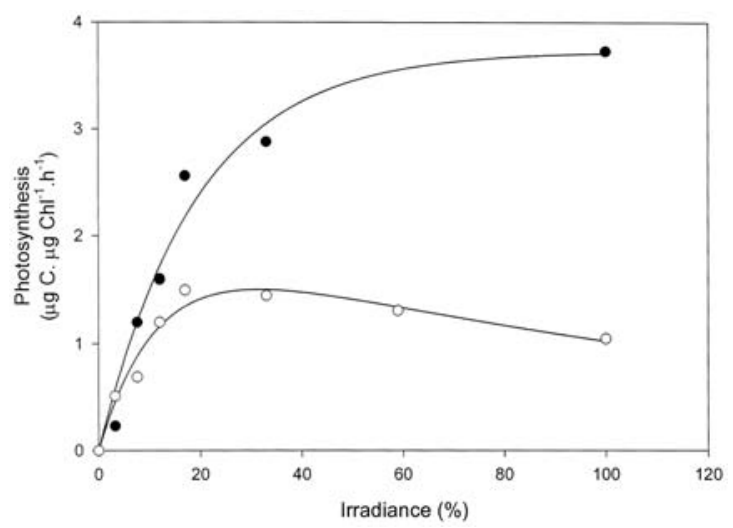

Figure 2. Photosynthesis versus irradiance curves measured on floating scums of Microchaete $(\bullet)$ and Anabaena $(\bigcirc)$ in August 1999 in Valencian rice-fields. Microchaete scums were collected from an area with scarce rice plants but Anabaena was collected from a very shaded area with high rice plant density. $\mathrm{C}$ assimilation experiments were conducted in situ using ${ }^{13} \mathrm{C}$ uptake (from $\mathrm{Na} \mathrm{H}^{13} \mathrm{CO}_{3}$ ). 100\% irradiance was $1331 \mu \mathrm{mol}$ photons $\mathrm{m}^{-2} \mathrm{~s}^{-1}$. The Webb model was used for fitting the curve and to determine the photosynthetic parameters. Curvas de fotosintesis frente a irradiancia determinadas en afloramientos flotantes de Microchaete (•) y Anabaena (O) en agosto de 1999 en arrozales valencianos. Los afloramientos de Microchaete se recogieron de un área con escasa plantas de arroz mientras que Anabaena se recogió de un área muy sombreada con alta densidad de plantas de arroz. Los experimentos de asimilación de $C$ se realizaron in situ utilizando la toma de ${ }^{13} \mathrm{C}$ (desde $\mathrm{Na} \mathrm{H}^{13} \mathrm{CO}_{3}$ ). El 100\% de irradiancia durante el ensayo correspondió como término medio a 1331 umol de fotones $m^{-2} s^{-1}$. Para la obtención de los parámetros fotosintéticos se utilizó el ajuste de Webb. curves determined with cyanobacterial blooms in August demonstrated that Microchaete sp. obtained from an area with scarce rice plants (i.e. high light conditions) had drastically different photosynthetic characteristics than the Anabaena sp. bloom, obtained from a shaded area. Anabaena, showed lower maximum photosynthesis $\left(2.02\right.$ vs. $\left.3.73 \mu \mathrm{g} \mathrm{C} \mu \mathrm{g} \mathrm{chl}^{-1} \mathrm{~h}^{-1}\right)$ than Microchaete which did not present any photoinhibition (Fig. 2). Nevertheless, the values of $\alpha$ (the slope of the curve in the proportional section of the function) and $\mathrm{I}_{\mathrm{k}}$ (the irradiance value from which the photosynthetic activity is saturated) were not different between both species $\left(0.19\right.$ and $0.16 \mu \mathrm{g} \mathrm{C} \mu \mathrm{g} \mathrm{chl}{ }^{-1} \mathrm{~h}^{-1}$ $/ \mu \mathrm{mol}$ photon $\mathrm{m}^{-2} \mathrm{~s}^{-1}$ for Anabaena and Microchaete respectively for $\alpha$ and 123 and 162 $\mu \mathrm{mol}$ photon $\mathrm{m}^{-2} \mathrm{~s}^{-1}$ for $\mathrm{I}_{\mathrm{k}}$ respectively).

In September rice plants are at the maximum height (more than $1 \mathrm{~m}$ ) and consequently the canopy is very intense, PAR at the water surface is on average $5.7 \%$ of the air irradiance. Our data demonstrate that planktonic cyanobacterial abundance decreases severely at the end of the cultivation cycle (Quesada \& FernándezValiente, 1996). The cyanobacteria counted in the first $5 \mathrm{~mm}$ of the sediment, which is one of the niches with maximum cyanobacterial abundance, also decreased at the end of cycle, by $45 \%$ with respect to initial values (Quesada \& Fernández-Valiente, 1996). Nevertheless, the photosynthetic parameters measured in floating blooms of two cyanobacteria at this moment indicated that the one growing under high light, Microchaete, was severely light limited (a reduction of $75 \%$ the photosynthetic rate) with the typical rice canopy (5.7\% of air irradiance), but the one growing under low light, Anabaena, was not so limited (a reduction in the photosynthetic rate of $40 \%$ was measured). The reduction in light availability is not due only to the light intensity but also to the light quality. As the rice plant grows the canopy produces a reduction in the intensity but also a shift in the light quality, since the rice plant's chlorophyll $a$ absorbs most of the photosynthetic useful photons, leading to an environment dominated by green light. 
However, cyanobacteria are especially well adapted to this light and phycobiliproteins and particularly phycoerythrin allow them to obtain energy from light dominated by green wavelengths for photosynthesis (Quesada et al. 1998).

\section{Drying and rewetting}

Alternate periods of drying and rewetting may also influence the composition of algal biomass. Akinetes-forming (resistance forms) cyanobacteria have a high capacity to withstand desiccation and are favoured by long periods of drying. In the rice-fields of Senegal, akinetes of heterocystous cyanobacteria constituted more than $95 \%$ of potential flora at the end of the dry period which lasts 8 months. In direct observation of sediments under epifluorescence microscopy, rice-field soils from Valencia showed also a high proportion of resistance forms.

\section{Predation}

Grazers are the most important biotic factor affecting photosynthetic aquatic biomass. Cladocerans, copepods, ostracods, rotifers, chironomid and mosquito larvae, and snails are common grazers of algae in rice-fields (Roger, 1996). A survey of aquatic invertebrates in ricefields in Philippines showed that ostracods, copepods, cladocerans, mosquito and chironomid larvae can develop significant populations densities. Among those, ostracods were the most abundant, reaching densities higher than $3 \cdot 10^{4} / \mathrm{m}^{2}$ (Simpson et al., 1994). Grazing rates of ostracods on monospecific cultures of cyanobacteria varied from 1 to more than $100 \mu \mathrm{g}$ dry wt /ostracod per day (Grant et al., 1983). In Mediterranean rice-fields, rotifers and cladocerans are the dominant components of zooplankton during the first phases of rice growth. During the tillering phase, copepods displace rotifers and cladocerans, forming the most abundant zooplankton population. In the last phases of rice cultivation, ostracods become the most abundant group (Forés \& Comín, 1992). However, the susceptibility of algae to grazing varied depending on the species. As a general trend among cyanobacteria, filamentous strains or mucilaginous colonies are less susceptible to grazing (Roger, 1996).

\section{Agronomical practices}

Agronomic practices have also a clear influence on the biotic component of the rice-fields, and particularly on cyanobacterial population. $\mathrm{N}$ fertilizer application increased the number of planktonic and filamentous eukaryotic algae (Yoshida et al., 1973) but decreased the population of $\mathrm{N}_{2}$-fixing cyanobacteria and their ability to fix dinitrogen (Carreres et al., 1996), although the effect of $\mathrm{N}$ fertilizers on $\mathrm{N}_{2}$ fixation is less pronounced in the field than in the laboratory (Prosperi et al., 1992). The use of pesticides also affects photosynthetic aquatic biomass. Cyanobacteria may tolerate high levels of pesticides, higher than those recommended for field application (Orús et al., 1990; Leganés \& Fernández-Valiente, 1992). Several reports indicate a selective effect of algicides on green algae, which promotes cyanobacterial growth (Yamagishi \& Hashizume, 1974). Likewise it has been reported that cyanobacterial growth is favoured by the use of insecticides which inhibit the populations of grazers and have a selective effect on green algae (Tirol et al., 1981). However, in experiments in the rice-fields of Valencia (Spain) no effect of insecticide application on the number of cyanobacteria and $\mathrm{N}_{2}$ fixation was found (Leganés et al., 2001). Herbicides seem to be the most detrimental pesticides to algae and cyanobacteria, causing partial or total inhibition of growth (Roger, 1996)

\section{SEASONAL VARIATION OF AQUATIC PRIMARY PRODUCTION}

The complexity of this ecosystem, in which organisms from several habitats coexist in very tight relationship (the planktonic, the benthic and the epiphytic environments), does not allow to identify easily the activities from each habitat 


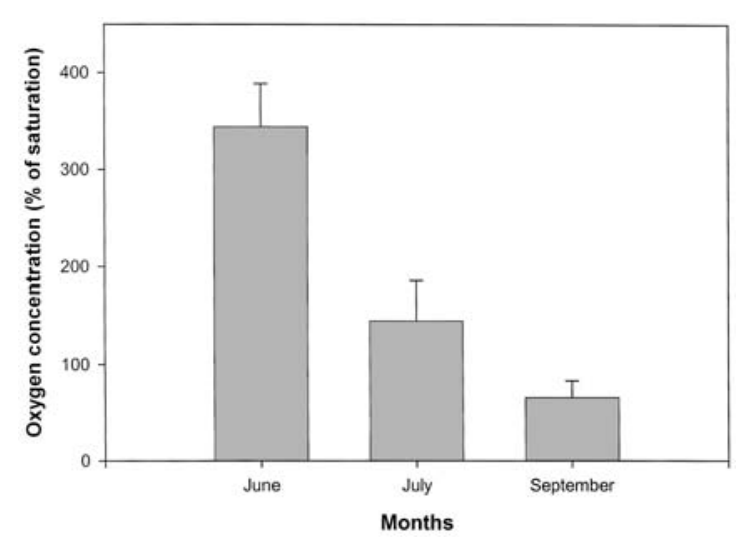

Figure 3. Oxygen concentration variation, expressed as \% of saturation, along the rice cultivation period in Valencian ricefields. Data were obtained in 1992 at solar noon during 4 consecutive days simultaneously at 5 different sampling points at each sampling month. The bar represents the average of all values for each month and the error bar is the standard variation of the mean. Variación en la concentración de oxígeno, expresada como \% de saturación, a lo largo del ciclo de cultivo en los arrozales valencianos. Los datos se obtuvieron en 1992 al mediodia solar durante 4 dias consecutivos y simultáneamente en 5 puntos de muestreo distintos durante cada campaña de muestreo (mensual). La barra representa la media de todos los valores obtenidos para cada mes y la barra de error representa la desviación estándar de la media.

and a complete ecosystem approach is more appropriate. This holistic approach necessarily involves the water, which integrates the activities and limitations for all the submerged habitats.

At the beginning of the season the primary production is very intense, leading to oxygen supersaturation, when the measuring probes read even more than $300 \%$ saturation. However, by night the respiration reduces drastically the concentration, yielding values as low as $20 \%$ of saturation. The variation of the oxygen concentration along the crop season is also very marked (Fig. 3) and follows the light availability, indicating that primary production in this ecosystem might be light-limited at the end of the cultivation period. The aquatic habitat shifts from a primary producers-dominated ecosystem to a consumers-dominated ecosystem. The decrease in the oxygen concentration is likely due to the observed severe reduction in the submerged macrophyte population, since the cyanobacterial blooms are still found, and our data indicate that they are well adapted to this low irradiance condition.

Dissolved inorganic carbon (DIC) and $\mathrm{pH}$ also change along the crop period. Before the plants shade sufficiently the water layer, both, DIC and $\mathrm{pH}$ change intensely along the day, DIC decreases after the sunrise, getting the minimum values during the afternoon.

As DIC decreases $\mathrm{pH}$ increases, reaching extremely high values during the afternoon. Both variables are dominated by the primary production, since the reduction in DIC is due to the $\mathrm{C}$ uptake by the photosynthetic organisms, and the increase of $\mathrm{pH}$ is mediated by the displacement of the chemical equilibrium towards the production of $\mathrm{OH}^{-}$, with the consequent $\mathrm{pH}$ increase (Whitton et al. 1988c). This direct relationship allows to predict the primary production (as oxygen evolution) from a simple measurement of $\mathrm{pH}$ (Fig. 4 A). However, this relationship is only direct $\left(\mathrm{r}^{2}=0.539, \mathrm{p}<0.001\right)$ in June $(\mathrm{pH}=7.67+0.004 *$ Oxygen $\%$ of saturation) when there is no light limitation. Later on in the crop period, this relationship starts to become poorer (Fig.s 4B and 4C) and in fact does not allow the prediction in September $\left(r^{2}=0.055, p>0.05\right)$. Similar results have been described by Whitton et al (1988c) in ricefields from Bangladesh, with good relationships between $\mathrm{pH}$ and oxygen concentration in surface but apparently non significant relationships at the bottom of the deep water ecosystems (over $2 \mathrm{~m}$ deep).

While in lakes typically, except in very eutrophic ones, the variation in $\mathrm{pH}$, oxygen concentration and DIC along the day is moderate or negligible, rice-fields are peculiar because when light is not limiting, the variation in these variables is very pronounced. The main difference between the investigated rice-fields and lakes is that the limiting factor in the former is light, but nutrients at the surface in the second.

The dynamic variation in the water physical and chemical features in this flowing ecosystem driven by light indicates that biological activities are very important in short term cycles. The 

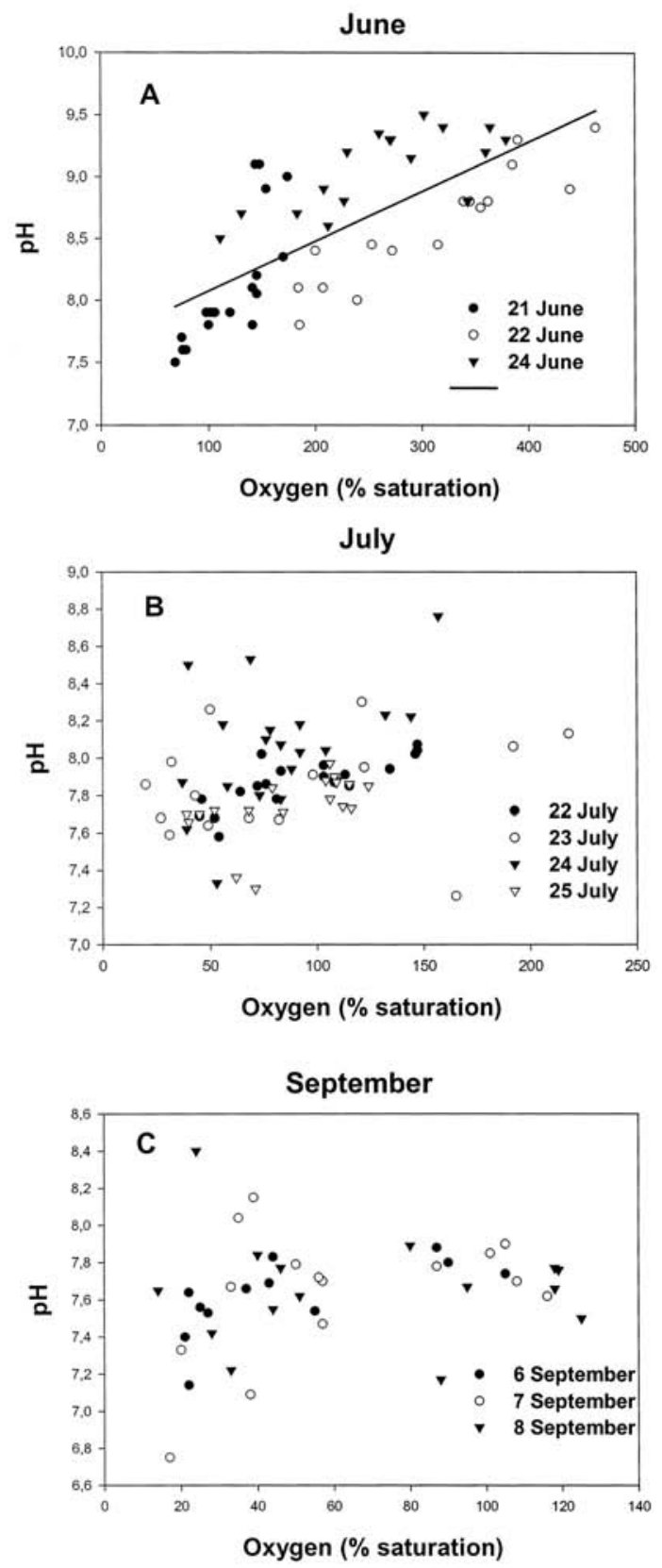

Figure 4. Relationship between oxygen concentration, as \% of saturation, and $\mathrm{pH}$ in three different moments of the rice cultivation period in 1992 in Valencian rice-fields. Every plot shows the daily variation from 9 to $15 \mathrm{~h}$ in at least 3 sampling points, during several consecutive days. Relación entre la concentración de oxígeno, como \% de saturación, y pH en tres momentos distintos del ciclo de cultivo del arroz en 1992 en arrozales valencianos. Cada gráfica representa la variación diaria de estas variables de 9 a $15 \mathrm{~h}$ en al menos 3 puntos de muestreo, durante varios días consecutivos. implications of these cycles are not completely understood but most probably represent an important source of variation, changing the nutrient chemical availability, or the ecological relationships among trophic groups. This aspect is not usually found in lakes because they have a higher momentum. In lakes the relationship between sediment and water is not so important as is in rice-fields. These findings may have deep implications in other shallow ecosystems, as estuaries, shallow lakes, or wetlands.

\section{PHOTOSYNTHETIC AQUATIC BIOMASS AND NITROGEN FIXATION}

Studies comparing $\mathrm{N}$ balance in the presence and the absence of light in the water and surface soil indicates that, on average, photodependent $\mathrm{N}_{2}$ fixation contributes to $2 / 3$ of the balance (Roger, 1995). These results agree with diel measurements of $\mathrm{N}_{2}$ fixation (acetylene reducing activity; ARA) in the rice-fields of Valencia which indicates that $\mathrm{N}_{2}$ fixation during daytime contributes to $75 \%$ of the total activity of the day (2810 $\mu \mathrm{mol}$ ethylene $/ \mathrm{m}^{2}$ during daytime and 672 $\mu \mathrm{mol}$ ethylene $/ \mathrm{m}^{2}$ during the night) (Quesada $e t$ al., 1998). Comparison of assays of acetylene reducing activity in the light and in the dark in the rice-fields of Bangladesh also indicates a marked decrease of the activity in the dark (Rother et al., 1988; Rother \& Whitton, 1989).

Studies performed during the last 15 years in the rice-fields of Valencia (Spain) showed a high spatial and temporal variability of nitrogen fixation. It was measurable at all sampling sites in at least one sampling period. Mean values of assays performed where no cyanobacterial presence was evident ranged from 12.9 to 108.7 $\mu$ mol ethylene $\mathrm{m}^{-2} \mathrm{~h}^{-1}$. These values are in the range to those reported for rice-fields from Bangladesh (Rother \& Whitton, 1989) and Philippines (Reddy \& Roger, 1988; Roger et al., 1988) and represent from 0.23 to $75.5 \mathrm{~kg} \mathrm{~N}$ fixed $\mathrm{ha}^{-1} \mathrm{crop}^{-1}$ in Valencian rice fields. Nitrogen fixation measured on cyanobacterial blooms reached $2500 \mu \mathrm{mol}$ ethylene $\mathrm{m}^{-2} \mathrm{~h}^{-1}$, a 


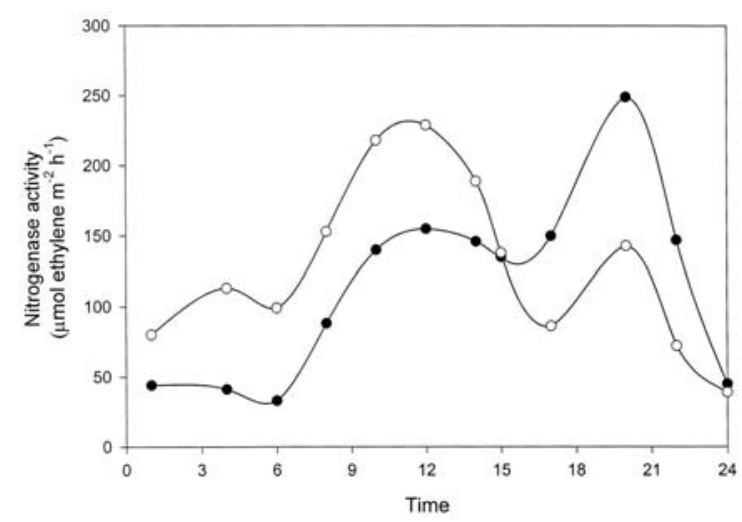

Figure 5. Daily variation of nitrogenase activity, measured as acetylene reducing activity, in Valencian rice-fields during $1994(\bullet)$ and $1995(\bigcirc)$. The data shown are the average for three incubation chambers measured in three different moments of the rice cycle (June, July and September), $n=9$. The standard deviation was lower than $20 \%$ of the mean. Variación diaria de la actividad nitrogenásica, medida como actividad reductora del acetileno en arrozales valencianos durante 1994 (@) y 1995 (O). Los datos mostrados son la media de tres cámaras de incubación medidos en tres momentos distintos del periodo de cultivo (junio, julio y septiembre), $n=9$. La desviación estándar fue inferior al $20 \%$ del valor de la media.

value twofold higher than the maximum value obtained when no bloom was visible (Quesada et al., 1997), representing $2 \mathrm{~kg} \mathrm{~N} \mathrm{ha}{ }^{-1}$ day $^{-1}$ (Quesada et al., 1997), which depending on the duration of the bloom may represent similar values than those reported in rice-fields from Philippines (Roger et al., 1988), ranging from 0.2 to $50 \mathrm{~kg} \mathrm{~N} \mathrm{ha}^{-1} \mathrm{crop}^{-1}$.

Nitrogen fixation shows a general bimodal pattern of daily variation, with peaks of activity at noon and in the evening and lower values at morning, afternoon and during the night (Fig. 5) (Quesada et al., 1998). Nitrogen fixation also showed a seasonal variation along the cultivation cycle (Fig. 6). Values increased from the beginning of the cultivation cycle to reach a maximum value at the tillering stage of rice plant, and declined thereafter until the end of the cycle. Similar patterns of daily and seasonal variation are reported in rice-fields from Philippines (Alimagno \& Yoshida, 1977).

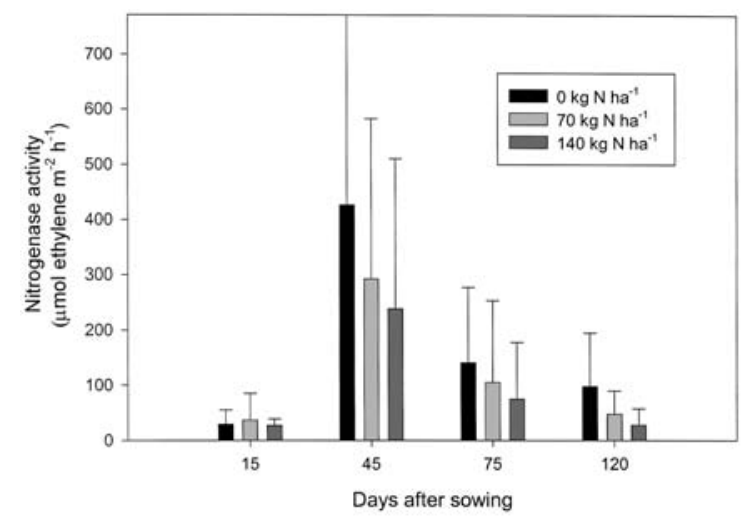

Figure 6. Variation of nitrogenase activity, measured as acetylene reducing activity, in Valencian rice-fields along the cultivation period as a function of fertilizer concentration. The data are the average of 5 years (1990-95), n ranged between 15 and 25 . The differences were significant considering all the data and comparing unfertilized plots vs. plots fertilized with the maximum concentration $(\mathrm{n}=108, \mathrm{p}=0.001)$. Variación de la actividad nitrogenásica, medida como actividad reductora del acetileno, en arrozales valencianos a lo largo del ciclo de cultivo en función de la concentración de fertilizante añadido. Los datos mostrados son las medias de 5 años (1990-1995), oscilando el valor $n$ entre 15 y 25. Las diferencias fueron significativas agrupando todos los datos y comparando campos con la máxima fertilización y campos sin fertilizar $(n=108, p=0.001)$

Environmental variables that correlated with ARA varied on a seasonal basis. Water properties such as calcium, hardness and conductivity, and soil properties such as conductivity and sodium content correlated positively with ARA; however, nutrient parameters such as dissolved inorganic nitrogen or soluble reactive phosphorus were negatively correlated (Quesada et al., 1997). No clear correlation between nitrogen fixation and cyanobacterial abundance in soil was found in these studies (Quesada et al., 1997). Recent studies in the rice-fields of Valencia indicates that nitrogen fixation by epiphytic cyanobacteria on Chara accounts for more than $70 \%$ of the global activity of the ecosystem (Ariosa, 2002). This fact would explain the poor correlation previously found between nitrogen fixation and soil cyanobacteria. As a general trend it has been demonstrated that the values of nitrogen fixation are always higher in unfertilised plots than 
in plots fertilised with urea or ammonium sulphate (Fig. 6) being the nitrogenase activity significantly different between unfertilized and maximum fertilization fields $(\mathrm{n}=108 ; \mathrm{p}=0.001)$ (Roger et al., 1988; Carreres et al., 1996; Fernández-Valiente et al., 1997).

Azolla is an aquatic fern that harbours the symbiotic $\mathrm{N}_{2}$-fixing cyanobacteria Anabaena azollae. Because of its rapid growth, its high $\mathrm{N}$ content, and its ability to grow together with rice in submerged soils, Azolla has been used as green manure in rice culture in many countries (Roger \& Ladha, 1992; Watanabe \& Liu, 1992). However, its spontaneous development is less frequent than that of free-living cyanobacteria, in such a way that fields usually need to be inoculated with Azolla when it is to be used as green manure (Roger, 1996). Experiments performed in different countries, using the ${ }^{15} \mathrm{~N}$-dilution method show that $70-80 \%$ of $\mathrm{N}$ accumulated by Azolla is derived from $\mathrm{N}_{2}$ fixation (Kumarasinghe \& Eskew, 1993). Nitrogen-fixing rates in inoculated fields with maximum standing crop of Azolla ranged from 0.4 to $3.6 \mathrm{~kg} \mathrm{~N} / \mathrm{ha}$ per day (Roger \& Watanabe, 1986). Nevertheless, Azolla species have not been found, at least since 1986, in the Valencia rice-fields.

\section{CONCLUSIONS}

The rice-fields are extensive shallow aquatic ecosystems with an important anthropogenic management, which regulates completely the ecosystem, including the dry-wet cycles and the nutrient input. Photosynthetic aquatic biomass in Valencian rice-fields is dominated by cyanobacteria and macrophytic algae as Chara. Ricefields can be considered eutrophic, since the nutrient load is typically very high and at certain moments cannot be considered limiting, and other environmental variables might be the responsible for the limitation of the primary producers. Irradiance availability, both intensity and quality, divides the crop cycle in two periods. The first period occurs when plants are short and do not reduce the irradiance availability, at this moment the characteristics of the water layer change in accordance to primary production, increasing oxygen concentration and $\mathrm{pH}$, but decreasing DIC concentration. The second period takes place when the plant canopy is intense and irradiance decreases being particularly rich in green wavelengths, which is only useful for cyanobacteria, in this period global primary production is limited and is not able of changing the water chemical characteristics. Nitrogen cycle in this ecosystem is particularly dominated by $\mathrm{N}_{2}-$ fixation, since the aquatic biota is dominated by $\mathrm{N}_{2}$-fixing cyanobacteria. In spite of the fertilizer input typically applied in the rice-fields, $\mathrm{N}_{2}$-fixation is quantitatively important reaching values close to $75 \mathrm{~kg} \mathrm{~N} \mathrm{ha}^{-1} \mathrm{y}^{-1}$, which may represent an input of $75 \mathrm{mg} \mathrm{N} \mathrm{1}^{-1} \mathrm{y}^{-1}$.

\section{ACKNOWLEDGEMENTS}

We are in debt to all scientists and students who helped in the field work, during these 16 sampling seasons. We thank especially Dr. Leganés who worked very hardly in most of the samplings and contributed notably to the discussion of results during all these years, and Dr. Carreres who made possible the field work in experimental areas, and the collaboration between biologists and agronomists. This work has been funded by Ministerio de Educación y Ciencia and Comisión Interministerial de Ciencia y Tecnología (Spain) with the grants: PB85-0280; AGR89-0217-CO2-01; AGF93-0807-CO2-01; AGF97-0303-CO2-01; AGL2001-1626-CO2-01

\section{REFERENCES}

ALIMAGNO, B. V. \& T. YOSHIDA, T. 1977. In situ acetylene-ethylene assay of biological nitrogen fixation in lowland rice soils. Plant \& Soil, 47: 239-244.

ARIOSA, Y. , 2002. Influencia de los afloramientos de cianobacterias diazotróficas y del macrófito Chara vulgaris en el aporte de nitrógeno a la planta de arroz. Ph.D. Thesis. Universidad Autónoma de Madrid. Spain. 195 pp. 
AZIZ, A. \& Q. A. AHMED. 1991. Occurrence and biomass of Gloeotrichia epiphytic on deepwater rice plants near Sonargaon, Bangladesh. Bangladesh J. Bot., 20: 97-100.

AZIZ, A. \& Q. A. AHMED. 1992.Occurrence and biomass of algae epiphytic on deepwater rice plants near Sonargaon, Bangladesh. Arch. Hydrobiol., 125: 479-486.

CARRERES, R., R. GONZÁLEZ-TOMÉ, J. SENDRA, R. BALLESTEROS, E. FERNÁNDEZ-VALIENTE, A. QUESADA, M. NIEVA \& F. LEGANÉS. 1996. Effect of nitrogen rates on rice growth and biological nitrogen fixation. J. Agric. Sci., 127: 295-302.

FERNÁNDEZ-VALIENTE, E., A. QUESADA, C. PROSPERI, M. NIEVA, F. LEGANÉS \& A. UCHA. 1997. Short-term and long-term effect of ammonium on photodependent nitrogen fixation in rice-fields. Biol. Fertil. Soils, 24: 353-357.

FERNÁNDEZ-VALIENTE, E., A. QUESADA, M. NIEVA, F. LEGÁNES, C. PROSPERI, M. MARTÍN, R. CARRERES \& R. GONZÁLEZ. 1996. Contribution of biological nitrogen fixation to rice production in a Mediterranean rice field. In: Biological nitrogen fixation associated with rice production. M. Rhaman, (ed): 147-157. Kluwer Acad. Publish. Dordrecht. Netherlands

FORÉS, E. \& F. A. COMÍN, F. A. 1992. Ricefields, a limnological perspective. Limnetica, 8: 101-109.

GRANT, I. F., E. A. EGAN \& M. ALEXANDER. 1983. Measurement of rates of grazing of the ostracod Cyprinotus carolinensis on blue-green algae. Hydrobiologia, 106: 199-208.

GRANT, I. F., P. A. ROGER \& I. WATANABE. 1986. Ecosystem manipulation for increasing biological $\mathrm{N}_{2}$ fixation by blue-green algae (Cyanobacteria) in low land rice fields. Biol. Agric. Hortic., 3: 299-315.

GUPTA, A. B., 1966. Algal flora and its importance in the economy of rice fields. Hydrobiologia, 28: 213-222.

KULASOORIYA, S. A., P. A. ROGER, W. L. BARRAQUIO \& I. WATANABE. 1981. Epiphytic nitrogen fixation on weeds in rice field ecosystem. In: Nitrogen cycling in Southeast Asian wet monsoonal ecosystem. R., Wetseelaar, J.R. Simpson \& T. Roswall (eds): 56-61. Australian Academy of Science, Canberra. Australia

KUMARASINGHE K. S. \& ESKEW, D. L.1993. Isotopic studies of Azolla and nitrogen fertilization of rice. Kluwer Acad. Publish. Dordrecht. Netherlands $145 \mathrm{pp}$.
LEGANÉS, F. \& E. FERNÁNDEZ-VALIENTE. 1992. Effects of phenoxy acetic herbicides on growth, photosynthesis and nitrogenase activity in cyanobacteria from rice fields. Arch. Environ. Contam. Toxicol., 22: 130-134.

LEGANÉS, F., R. CARRERES, R. GONZÁLEZ TOMÉ, M. NIEVA, A. QUESADA, J. SENDRA \& E. FERNÁNDEZ-VALIENTE. 2001. Effect of phosphate fertilisation, straw incorporation, insecticide application and inoculation with cyanobacteria on rice productivity. Invest. Agr.: Prod. Prot. Veg., 16: 273-282.

MARTÍN-TRILLO, M. M., 1995. Afloramientos masivos (blooms) de cianobacterias en los arrozales valencianos: Seguimiento de su desarrollo y caracterización de dos estirpes formadoras. M. Sc. Thesis. Universidad Autónoma de Madrid. Spain. 97 pp.

MINZONI, F., C. BONETTO \& H. L. GOLTERMAN. 1988. The nitrogen cycle in shallow water sediment systems of rice fields. Part 1: The denitrification process. Hidrobiología, 159: 189-202.

MISRA, A., G. K. PATRO \& G. C. TOSH. 1976. Studies on chemical control of Chara. In: Aquatic weeds in Southeast Asia. C.K. Varshney \& J. Rzoska (eds): 265-268. W. Junk, B.V. Publ. La Hague. Netherlands.

NEUE, H. U. 1988. Wholistic view of chemistry of flooded soil. In: Proceedings of the first international symposium on paddy soil fertility. Paddy Soil Fertility Working Group (eds.): 21-53. Chiang Mai, Thailand.

ORÚS, M. I., E. MARCO \& F. MARTÍNEZ. 1990. Effect of trichlorfon on $\mathrm{N}_{2}$-fixing cyanobacterium Anabaena PCC 7119. Arch. Environ. Contam. Toxicol., 19: 297-301.

PROSPERI, C., L. BOLUDA, C. LUNA \& E. FERNÁNDEZ-VALIENTE. 1992. Environmental factors affecting in vitro nitrogenase activity of cyanobacteria isolated from rice-fields. J. Appl. Phycol., 4: 197-204.

QUESADA, A. \& E. FERNÁNDEZ-VALIENTE. 1996 Relationship between abundance of $\mathrm{N}_{2}$-fixing cyanobacteria and environmental features of Spanish rice fields. Microb. Ecol., 32: 59-71.

QUESADA, A., F. LEGANÉS \& E. FERNÁNDEZVALIENTE. 1997. Environmental factors controlling $\mathrm{N}_{2}$-fixation in Mediterranean rice-fields. Microb. Ecol., 34: 39-48.

QUESADA, A., E. SÁNCHEZ-MAESO \& F. FERNÁNDEZ-VALIENTE. 1995. Seasonal varia- 
tions in the physical and chemical characteristics of a shallow water ecosystem, the ricefields of Valencia, Spain. Arch. Hydrobiol., 132: 495-511. QUESADA, A., M. NIEVA, F. LEGANÉS, A. UCHA, M. MARTÍN, C. PROSPERI \& E. FERNÁNDEZ- VALIENTE, 1998. Acclimatization of cyanobacterial communities in rice-fields and response of nitrogenase activity to light regime. Microb. Ecol., 35: 147-155.

REDDY, P. M. \& P. A. ROGER. 1988. Dynamics of algal populations and acetylene-reducing activity in five soils inoculated with blue-green algae. Biol. Fertil. Soils, 6: 14-21.

ROGER, P. A., 1995. Biological $\mathrm{N}_{2}$-fixation and its management in wetland rice cultivation. Fertil. Res., 42: 261-276.

ROGER, P. A., 1996. Biology and management of the floodwater ecosystem in ricefields. International Rice Research Institute, Los Baños, Philippines, $250 \mathrm{pp}$.

ROGER, P. A. \& J. K. LADHA. 1992. Biological $\mathrm{N}_{2}$ fixation in wetland rice fields: Estimation and contribution to nitrogen balance. Plant \& Soil, 141: 41-55.

ROGER, P. A. \& P. A. REYNAUD. 1976. Dynamique de la population algale au cours d'un cycle de culture dans une riziere Sahélienne. Rev. Ecol. Biol. Sol., 13: 545-560.

ROGER, P. A. \& I. WATANABE. 1986. Technologies for utilizing biological nitrogen fixation in lowland rice: potentialities, current usage and limiting factors. Fertil. Res., 9: 39-77.

ROGER, P. A., P. M. REDDY \& R. REMULLAJIMENEZ. 1988. Photodependent acetylene reducing activity (ARA) in ricefields under various fertilizer and biofertilizer management. In: Nitrogen fixation: hundred years after. H. Bothe, F. de Bruijn \& W.E. Newton (eds): 827. Gustav Fisher Pub. Stuttgart. Germany.

ROGER, P. A., W. J. ZIMMERMAN \& T. LUMPKIN. 1993. Microbiological management of wetland ricefields. In: Soil microbial ecology. B. Metting, (ed): 417-455. M. Dekker Pub. New York. USA

ROGER, P. A., S. SANTIAGO-ARDALES, P. M. REDDY \& I. WATANABE. 1987. The abundance of heterocystous blue-green algae in rice soils and inocula used for application in rice fields. Biol. Fertil. Soils., 5: 98-105.

ROTHER, J. A. \& B. A. WHITTON. 1989. Nitrogenase activity of blue-green algae on sea- sonally flooded soils in Bangladesh. Plant \& Soil, 113: 47-52.

ROTHER, J.A., A. AZIZ, N. HYE KARIM \& B. A. WHITTON. 1988. Ecology of deepwater ricefields in Bangladesh 4. Nitrogen fixation by bluegreen algal communities. Hydrobiologia, 169: 4356.

SIMPSON, I., P. A. ROGER, B. OFICIAL \& I. F. GRANT. 1994. Effects of fertilizer and pesticides management on floodwater ecology of a wetland ricefield. II. Dynamics of microcrustaceans and dipteran larvae. Biol. Fertil. Soils., 17: 138-146.

TIROL, A. C., S. T. SANTIAGO \& I. WATANABE. 1981. Effect of the insecticide carbofuran on microbial activities in flooded soil. J. Pestic. Sci., 6: 83-89.

VAQUER, A., 1984. La production algale dans le rizières de Camargue pendant la période de submersion. Ver. int. Verein. Limnol., 22: 1651-1654.

WATANABE, I., \& C. C. LIU. 1992. Improving nitrogen-fixing systems and integrating them into sustainable rice farming. Plant \& Soil, 141: 5767.

WHITTON, B. A. 2000. Soils and rice-fields. In: The ecology of cyanobacteria, their diversity in time and space. B.A. Whitton, \& M. Potts (eds): 233255. Kluwer Ac. Pub. Dordrecht. Netherlands

WHITTON, B. A. \& H. D. CATLING. 1986. Algal ecology of deepwater rice-fields in Thailand. Arch. Hydrobiol., 105: 289-297.

WHITTON, B. A., A. AZIZ, P. FRANCIS, J. A. ROTHER, J. W. SIMON \& Z. N. TAHMIDA. 1988a. Ecology of deepwater rice-fields in Bangladesh 1. Physical and chemical environment. Hidrobiología, 169: 3-67.

WHITTON, B. A., A. AZIZ, B. KAWECKA \& J. A. ROTHER. 1988b. Ecology of deepwater ricefields in Bangladesh 3. Associated algae and macrophytes. Hydrobiologia, 169: 31-42.

WHITTON, B. A., J. A. ROTHER \& A. R. PAUL. 1988c. Ecology of deepwater rice-fields in Bangladesh 2. Chemistry of sites at Manikganj and Sonargaon. Hydrobiologia, 169: 23-30.

YAMAGISHI, A. \& A. HASHIZUME. 1974. Ecology of green algae in paddy fields and their control with chemicals. Zasso Kenkyu, 18: 39-43.

YOSHIDA, T., R. A. RONCAL \& E. M. BAUTISTA. 1973 Atmospheric nitrogen fixation by photosynthetic microorganisms in a submerged Soil. Soil Sci. Plant Nutr., 19: 117-123. 
